\title{
Revolt from the Right: Russia's Right-Wing Students Between Conservatism and Radicalism
}

'Our "true Russians", encouraged by victory in the local town elections, have decided to form a society, the Double-Headed Eagle...it is worth paying attention to this organization, which aims to prevent revolutionary activities'. The report in the newspaper Kievskii golos (Kievan Voice) from February 1907 continued that members of the society were causing some disruption at the local university, threatening students that they considered to have liberal views with physical violence. Turning the high-minded proclamations of the Kiev student right on their head, the commentary added sarcastically after reporting on the disruptions that 'only the purest and best of Russia's youth are joining this organization'. ${ }^{1}$ The Double-Headed Eagle in Kiev was just one example of the mobilization of student opinion from the right in the late imperial period. Like other student clubs, it was linked to the wider emergence of right-wing parties and groups that appeared during the revolutionary year of 1905, and endured until the revolutions of 1917. In the case of the DoubleHeaded Eagle, it was associated most of all with the local branch of the Union of Russian People (URP), a very substantial rightist group that first appeared during October 1905; other student groups were linked to major right-wing (or 'monarchist') groups like the Russian Assembly, the Russian Monarchist Party (RMP), the Union of Russian Men (URM), and the Union of the Archangel Mikhail (UAM). The student rightists (also known as Academists in the literature) similarly claimed that they represented Russian Orthodoxy, autocracy and nationality. Like the right-wing groups just listed, Academists looked both forwards and backwards; they were caught in limbo between supporting long-established ideas that were part of Russia's conservative heritage, and the adoption of more radical, uncompromising ideas and practices. The dilemma of Russian conservatism in the late imperial period - 
supporting past principles in a time of revolutionary crisis - is what compelled the Academists into action. ${ }^{2}$

To the non-specialist, the 'Russian right' might almost seem a contradiction in terms, especially with regard to the pre-revolutionary period. But right-wing student groups, as well as attracting a lot of attention from contemporaries, were a solid presence and can prompt us to look afresh at some of the main challenges in the imperial state as Russia encountered modernity. The Academists first appeared in the Western borderlands - largely non-Russian regions of the empire - right at the start of the twentieth century. A student-organized demonstration in Khar'kov, held on 27 November 1903, attracted around 100 students in defence of what they saw as authentic, 'Russian' values of a strong autocratic state, Russian nationhood and Russian religion. ${ }^{3}$ But a larger and more voluble student movement from the right emerged in response to the revolution of 1905. In Kiev, Academist development appeared most pronounced from 1906-07. The Double-Headed Eagle was estimated to have 353 members in 1907, and 386 members towards the end of $1908 .^{4}$ This group drew the majority of its support from St. Vladimir University. ${ }^{5}$ In Odessa, police reports show that rightist groups had strong support from the end of 1905 through 1906, with figures of up to 20,000 being cited for the regional branch of the URP; this figure included several groups of right-wing students numbering 50 to 150 , which mobilized from New Russia University in the city. ${ }^{6}$ Elsewhere in the Russian Empire, right-wing student groups also appeared in tandem with the rise of larger right-wing associations. In Warsaw, the appearance of a group called the League of Monarchical Youth towards the end of 1907 typified the general trend; one police report estimated that there were around 870 URP members in the region, including members of the League. ${ }^{7}$ It is important to recognize that the student right was usually linked to major parties and groups: in $1907-08$, there were around 400,000 or so 
rightists distributed across dozens of provinces in the empire; this was a vast presence outnumbering all liberal and left-wing groups in the era even when combined. ${ }^{8}$

Academist groups continued to form throughout the late imperial period, up until the outbreak of the First World War, and, indeed, until the revolutions of 1917. For instance, another Academist club was opened at New Russia University on 5 December 1911. ${ }^{9}$ Archival documentation also shows that the activity of the Academist group at the Forestry Institute in St. Petersburg continued well into 191314. ${ }^{10}$ Another group appeared in Tomsk at the Technological Institute: Tomsk had been one of the earliest sites of right-wing mobilization. Up until the eve of the First World War, the Academist movement's ideas and practices were reported in sympathetic newspapers such as Golos russkogo (Voice of Russia), with editorials reporting on the establishment of a club called the Scientific, Literary and Artistic Circles of Russian Students. ${ }^{11}$ All in all, it can be reasonably estimated that between 1907-14 there were hundreds of Academists active at any one time, and possibly as many as several thousand, spread across dozens of branches across the Russian Empire, and mostly concentrated in the Western regions. ${ }^{12}$ The engagement of members, and their practices in expanding the public space for a radical alternative from the right, lent them a significance out of proportion to their numbers.

This assessment seeks to engage with the wider historiography that has emerged around Russian conservative history in recent years. There is now a substantial literature on Russian conservatism and the Russian organized right, much of which has appeared within the Russian Federation itself over the past few decades. Some of this scholarship treats all elements on the right half of the political spectrum as part of 'Russian conservatism'. ${ }^{13}$ Such authors have sought to emphasize the ideological principles that unified more moderate Russian conservatives and those 
further to the right. In many ways, the central figure in this discussion is the Minister for Education from 1833-49, Sergei Uvarov, and his 'triad' of Russian Orthodoxy, autocracy and nationality. This formulation had functioned as the official ideology of the Russian state since 1831-32, and had been the key thread of Russian conservative ideology throughout the entire nineteenth century. ${ }^{14}$ It is suggested that these shared ideas override differences in practice; in a recent review article, Mikhail Luk'ianov and Mikhail Suslov have stressed that the "difference between the "aristocratic" and "democratic" components of the Right was a difference much more in styles of public debate than in ideology and political strategy'. ${ }^{15}$ Alternatively, others have rejected of claims that right-wing associations (pravye partii in Russian) were radical, mass mobilized groups or fascists avant la lettre. ${ }^{16}$

This article takes a different view. Instead, it will make a case that though right-wing groups like the Academists did indeed cling to long-established conservative norms, particularly the importance of Russian religion and an autocratic state, some of their ideas and practices emerging on the eve of the First World War were quite radical. Most of all, what differentiated Russian rightists from more moderate conservative statesmen, such as Prime Ministers Sergei Witte or Petr Stolypin, or parliamentary groups like the Union of 17 October or the Nationalist Party, was their refusal to recognize political changes in Russia. ${ }^{17}$ Instead, they mobilized outside of the elected parliament, the State Duma (established in 1906), and cast much invective at all that they opposed. In addition to upholding the values of the Uvarov triad, they also displayed a widespread, vehement anti-Semitism, a predilection, if not always achievement, for mass mobilization, and a desire to secure a cross-class social base. Indeed, the populist-nationalist ideas of far right groups like the URP represented a new style of mass nationalist politics united around veneration of the fatherland, but also hatred of a number of enemies within it: trends present in 
many right-wing student groups. Unlike student groups on the far left, ${ }^{18}$ the Academist movement has have attracted little scholarly attention, even whilst the literature on other aspects of the right-wing movements in late imperial Russia has mushroomed. ${ }^{19}$ Two important exceptions, examining the phenomenon of student radicalism from the right as well as the left, are recent works by Susan Morrissey which situate the development of a student right in St. Petersburg as part of an emerging student consciousness that expressed 'mythologies of radicalism'. In contrast, this article will look only at right-wing ideas, and examine the position of the Academist movement between conservatism and a more radical right-wing politics emerging during and after the 1905 revolution in Russia, and the state's responses to the movement. ${ }^{20}$

This analysis focuses largely on examples drawn from St. Petersburg, Kiev, Odessa and Khar'kov - all central areas of right-wing activity. It starts with an assessment of the conservative origins of the student movement before 1905. Then, the focus will shift to the following years, and how the student movement presented an alternative vision for Russia's future. The third section will examine the use of violence by some of the most radical groups in Odessa and Kiev. The section will consider reasons for the longevity of the Academist movement; ultimately unsuccessful in their aims to restore Russia, or have millions of students join their cause, Academists nevertheless did mobilize a substantial presence until the eve of the First World War. As well as to looking at the ideology of the Academists themselves, this analysis will consider how the state responded to their activity. In particular, mobilization in borderland regions led to a dilemma about how to respond to the challenge of increased student activism from the right and the left; but, unlike the student far left, Academists were not insurrectionists and provided opportunities to be used to shore up a wider conservative resistance to far left activism in the Russian 
university. Yet the radical ideas and practices of the Academists generated unease amongst some of the state's key figures, leading to a divided response from the autocracy on how to deal with the challenge of student radicalism from the right as well as the left. This assessment will consider where the student right fitted into the instability caused by Russia's encounter with modernity.

\section{Conservative origins}

Like all major rightist groups, Academist movements followed the principles established by Sergei Uvarov's triad. Russian Orthodox religion was central to the Russian right, both as an ideological lodestone and to the symbolism of various groups. This is apparent from the earliest student clubs created, among which were the associations linked to the Russian Assembly, itself composed of society's elites with a predominantly cultural focus. First established in St. Petersburg, this association promoted an updated version Uvarov's triad, espousing a motto of 'God, tsar and fatherland'. ${ }^{21}$ The first branch of the nominally related 'Russian-students' group was established in Khar'kov in 1902, with activists echoing the leaders of the main organization in their defense of 'Orthodoxy, autocracy and nationality'. Mobilization was though occurring across the empire: 1902 also saw the formation of Dennitsa (Dawn) in St. Petersburg; Trud i nadezhda (Work and Hope) in Tomsk; and Edinenie-sila (Unity-Strength) and Rassvet (Breaking Light) in Odessa, all of which claimed to be bringing patriotic and religious values to Russia's student body. ${ }^{22}$ Leaders of the Russian Assembly such as D. P. Golitsyn, A. S. Viazigin, A. F. Rittikh and B. V. Nikol'skii desired to appeal to youth as part of a wider attempt to create a cross-estate social base, though these small associations displayed little ideological novelty, or, indeed, major divergence of any sort from existing groups such as the Assembly. ${ }^{23}$ 
In addition to their veneration of Russian religion, these small associations wanted to use what little influence they had to bolster state power; they believed in the supremacy of Russian autocracy. This is clear from the activities of leaders of the nascent student right. One of the leaders of the Russian-students group, S. Mandrukin, a law student at Khar'kov University, proposed drawing up a list of 'revolutionary' students and professors at the Khar'kov institute and handing this over to the government. ${ }^{24}$ Yet, though they wanted to work towards the autocracy, one should note that this group arose entirely separately from the state. Indeed, a number of police were sent to monitor these groups, and filed reports noting the public activity of such autonomous associations, which appeared to be generally quite low-key at this point. ${ }^{25}$ Given their desire to work with the government and limited ability (or apparent desire) to challenge public order, police were happy to tolerate the Russianstudents group. Furthermore, the techniques used by the Russian-students group were typical of autonomous conservative associations at this stage. The Russian Assembly itself established tearooms and meetings houses in Khar'kov soon after its formation, which would provide a venue for the students who congregated there to meet. The authorities had very little to worry about in the earliest stages of the movement. ${ }^{26}$

Yet trouble was brewing on the horizon. Conservative students were vexed by the prominent involvement of the wider student community in protests against the Russo-Japanese War (1904-05). Members of the Khar'kov branch of the Russian Assembly such as A. Kaut and A. S. Viazigin had recognized student protest as a major problem for the stability of the Russian Empire before the revolution of 1905: they realized that the unrest of Russia's student youth at contemporary developments, and the coalescing of left-wing opposition to the state's policies and ideas, would in future form a focus point for civic disorder. Among the earliest indicators were 
student involvement in riots and strikes following the failed war against Japan, and the involvement of students in the Banquet Campaign of and their membership within the Union of Liberation (both in 1904). ${ }^{27}$

Therefore, it should be apparent that even before the Revolution of 1905 and the formation of a much larger organized right there was the potential for a larger student movement rising against the left. This was especially the case in the Western borderlands of the Russian Empire; Russia's right-wing students also shared the third and final principle of Uvarov's triad: they were avowedly nationalist. The strongest attestation of this is their appearance in these peripheral regions, which had large proportions of national minorities and Jewish students, sometimes involved in revolutionary movements, which provided a clearly defined 'other' for rightist students to react against. ${ }^{28}$ In Kiev, Boris Iuzefovich, a leader of the Russian Assembly and convener of another group called Pravogo poriadka (Law and Order), realized that a cross-class basis could be created for the Russian right. As a consequence, his speeches were often delivered to youth branches of the organized right in Kiev, such as the Russian Assembly before 1905, as well as a number of other workers' groups. Iuzefovich together with his supporters in the region worked hard to attract students to the movement, often delivering lectures aimed at students, opining on the threats that revolutionary doctrines posed to the Russian university and particularly how these people sought to corrupt Russian youth. Mobilization in Kiev is represented by the formation of several student groups, both before and after the revolution of 1905. Like the Russian-students group and the Russian Assembly, 'God, Tsar and Fatherland' were central principles of these societies: a distinct echo of Uvarov's triad. As well as attending Iuzefovich's lectures, members also joined aid societies and became involved in a number of nominally linked civic society groups. ${ }^{29}$ 
As seen from their adoption of Uvarov's principles, the ideologies of the nascent student right did not contain much in the way of radicalism, or, indeed, intellectual novelty of any sort. Additionally, their activities before 1905 appeared to be almost entirely pacific in character. Though there was a more vehement message emerging from within the Russian right more generally - the Assembly's members, such as the journalist Pavel Krushevan, could espouse a more populist and nationalist journalism on tense occasions such as in the run-up to the Kishinev Pogrom of 1903 the student right did not appear to be aiming for fundamental changes in Russian society at this stage. ${ }^{30}$ What changed this in the most fundamental way was the revolution of 1905, which led to wider political mobilization from the autonomous right that in turn created a larger student movement.

\section{The turn towards radicalism}

1905 transformed the consciousness of Russia's conservative students. ${ }^{31}$ More than anything else, it created deep unease, despair and pessimism amongst student observers who sympathized with the ethos and institutions of the autocracy. A letter from a student at St. Vladimir University in Kiev, Vladimir Sukhorukov, published in the conservative journal Grazhdanin (Citizen), claimed that a small yet vocal number of radical leftists had led to the closure of Russia's educational institutions. He added that the vast majority of students had no desires other than to study and learn, and the brilliance of Russian education was threatened by left-wing mobilization. ${ }^{32}$ Sukhorukov's concerns were echoed by developments elsewhere, with the riots, strikes and unrest of 1905 leading to the radicalization of sections of Russian conservative opinion. Most of all, it was the revolution of 1905 that lay behind the rapid expansion of the Academist movement. This is reflected by the creation of major right-wing groups, including the URP, towards the end of the year that adopted 
a more populist and demagogical vision in their battle to restore Russia to a time before politics and parliament. The concessions that had been wrung out of the autocracy represented by the October Manifesto of 1905, including promises for civil and legal rights for minority groups, laws of religious toleration and the establishment of an elected parliament (the State Duma), were strenuously rejected. This led to the formation of new parties and groups on the right. ${ }^{33}$ Leaders of the right, such as the URP's chairman Aleksandr Dubrovin and his followers, still kept to the Uvarov triad of Orthodoxy, autocracy and nationality, but they interpreted it differently: a new element was their claim to be protecting 'the masses' against the liberal establishment. $^{34}$

The formation of the student right was slow at first due to the government's decision to shut the nation's universities during 1905 in response to widespread student unrest. But once the universities were reopened in September 1906, the development of the Academist movement began afresh, freed from the cloying restraints of the tsarist state. ${ }^{35}$ Leading figures on the right, both publicists and activists, saw that they could use the revolutionary energies unleashed during 1905 in the service of creating a larger movement. Examples included the creation of an Academist group at the Forestry Institute in the suburbs of St. Petersburg under the guidance of Grigorii Ivanovich Kushnyr'-Kushnarev during 1906, known as Znanie (Banner), which reflected activity in the periphery of the Russian Empire. For instance, the largest of the groups established in Kiev was the Double-Headed Eagle, which was active from 1906-07 up until 1917. The group was composed of students from the nearby university, and at one stage had several hundred members. Elsewhere, the congress of the First All-Russian Union of Student Academists met in Moscow during 1906, inspired by a wider desire amongst the right-wing movements to oppose revolutionary ideologies and practices present in Russian universities. ${ }^{36}$ 
Other developments included the establishment of right-wing meetings houses for students: one appeared in Odessa, a particularly prominent site of right-wing mobilization, during $1907 .{ }^{37}$ Intriguingly, women-only branches of the student right were also set up, such as the Women's Patriotic Group from Moscow University, formed in 1907 under the watch of the leader of the Russian Monarchist Party, Vladimir Gringmut. ${ }^{38}$

The declarations of the groups that appeared from 1905-07, such as the Double-Headed Eagle in Kiev, can illustrate more radical aspects to Academist thought. Their ideas intersected closely with those of Uvarov and groups like the Assembly in that they proclaimed the supremacy of Russian Orthodoxy, Russian nationality, and an autocracy unconstrained by political developments. But what differentiated these student radicals from conservatives acting from within the state structures was how they refused to countenance many of the recent changes that had occurred in Russia. Most of all, this related to those enshrined in the October Manifesto. Activists fiercely decried the Russian present, and the revolutionary situation in particular. They sought to 'circulate amongst the Russian people our simple and truthful views and teachings, which will expose the lies, and will instead strengthen the devotion of the revolutionary Russian people to God, tsar and fatherland'. ${ }^{39}$ As well as harsh criticism of the status quo and a deep sense of unhappiness with recent developments, they also displayed populist ideas. Groups like the Double-Headed Eagle claimed that the masses of Russian people - workers and peasants - were a force for good, but a small yet powerful clique of socialists and bureaucrats had corrupted them during the revolution. ${ }^{40}$ The Double-Headed Eagle would oppose socialist doctrines through a concerted campaign of educating the people, adopting the following techniques: 
The publication of brochures and periodicals, in addition to the publication of patriotic books and articles, specifically designed for general reading room conversation and to benefit the population by teaching them the true meaning of the imperial rescript, manifesto and so on; to counter speeches by socialists and various other groups...the organization of meetings, reading rooms, dance, musical and literary evenings, the creation of libraries for these purposes and to hold books, newspapers and periodical publications... ${ }^{41}$

Ideas of training in religious Orthodoxy, respect for the Tsar and the Russian state were to be encouraged, views shared by the national right-wing groups that widely corroborated his view of the importance of education. Vladimir Purishkevich, the leader of the UAM (formed in 1908), organizer of the student right and delegate to the third and fourth State Dumas, described school as the locus where the 'spiritual unity' of the future Russian nation would be sought. ${ }^{42}$

Encouraged by Purishkevich, students in St. Petersburg attempted to mobilize what they termed 'intelligent and party-less' students (an allusion to left-wing politics) against tendencies of left-wing student radicalism. These ideas were disseminated from the main council of the Union in a propaganda drive aimed at the majority of Russian students, tactics also adopted by the Znanie group at the Forestry Institute in St. Petersburg under the guidance of Kushnyr'-Kushnarev. ${ }^{43}$ Academists sought to explain the degeneration sweeping the nation and where it came from. Changes in Russian schooling were necessary due to national decline, and, in particular, due to the corrosive effects of political revolution in 1905. This degeneracy could be represented in explicit terms. A report in the Russian Assembly's journal Peaceful Work (Mirnyi trud), penned by the publicist A. Kaut, pointed to a promiscuous student body with a high rate of sexually transmitted diseases as one outcome of political revolution. Student suicide was another central concern. ${ }^{44}$ 
A major feature of the radicalism of the new right was the aggression in their ideologies, and inward looking desires to protect the 'truly Russian' people and an autocratic state. Leaders and activists on the student right highlighted a number of ethnic, moral and political causes as having a deleterious effect on the Russian people. Polish citizens were equated with Roman Catholic (and therefore non-Orthodox) religion, and Finns with socialist tendencies. The most widespread of such attitudes, however, was anti-Semitism. This theme was hardly unique to the Academists, but it was particularly widespread and deep-seated amongst their groups. Academist students claimed that Jews were overrunning Russia's educational establishments, and that their numbers dwarfed those of the right, and had led to a crisis in Russia's universities. ${ }^{45}$ Circulars from clubs such as the St. Petersburg Academic Union, influenced by leading figures on the right such as Vladimir Purishkevich, included claims that the number of Jews at the university needed to be kept to 'less than 10 per cent'. Claiming to be uncovering a Jewish conspiracy to subvert Russia, the Union added that St. Petersburg University was 'controlled by Jews'. ${ }^{46}$ One letter from an Academist student M. Klestov, written to Purishkevich on 18 October 1910, accused Jews (tellingly described by the pejorative 'yid' [zhid'], rather than the more neutral 'Jew' [evrei] in the telegram) as creating moral decrepitude in Russia's students through the sale of scurrilous literature:

In 1907 a...Jew opened a shop in Moscow called 'Secret life' which distributed pornography to Russia's youth. The city governor Gershel'man in Moscow, and later city governor in St. Petersburg, closed this shop. Then, changing the signs, he started a shop 'Life' which sold a wide range of books, which, in direct view of all and sundry, included revolutionary books. ${ }^{47}$

In another student letter, Jewish students were claimed to be dominating Russia's schools and universities and stealing money from Russian students. ${ }^{48}$ The anti-Semitic 
themes that these groups manipulated took many forms, with older religious concepts existing alongside newer conceptions of Jews being involved with revolution and politics. Underscoring this was a wider fear that minorities were corrupting the minds of Russia's youth during the revolutionary years of 1905-07; the vehemence of the student right's anti-Semitism extended to frequent threats against Jewish populations, and, occasionally, physical violence.

As well as the sheer vehemence of the student right, alternative plans for the restoration of Russian education and to halt contemporary degeneration were adopted. One of these themes was the proclamation of the virtues of 'Russian science'. Major monarchist groups such as the RMP, when led by their founder Vladimir Gringmut, had previously linked education in Russia to a phenomenon they termed 'true science'. ${ }^{49}$ Right-wing student groups took an idea of the supremacy of Russian scientific achievement and fused it to their own agenda; this was a complex response to Russian modernity, taking elements of what activists saw as technical progress and allying these concepts with a reactionary politics. ${ }^{50}$ The Academic Union at the St. Petersburg Polytechnic Institute, inspired by Purishkevich, claimed 'school - for science!' in opposition to the revolutionary doctrines that appeared as a result of political subjects, which had led to the disorders and unrest at Russian universities. ${ }^{51}$ Activists were united in praising 'Russian science' and nationalism simultaneously, and linked them closely. The proceedings of the a student group linked to the Russian Assembly stated, 'in physics, in chemistry, and generally in the natural sciences, it is possible to discern our national perspective, our national point of view' ${ }^{52}$

N. I. Nikol'skii, a student at Warsaw University, in his communications with Purishkevich declared the excellence of Russian educational institutions to be based 
around an objective desire for knowledge. He placed this in stark contrast to the damaging effects of 'modern politics':

I only want to see our educational institutions be peaceful, and I do not want to see our schools - temples of science - turn into political arenas, and turn away from science and towards politics. Furthermore, as a student, I have come to believe that schools must stand above all politics, that they must be purely Russian in spirit and thought. ${ }^{53}$

Like many right-wing students and clubs, Nikol'skii also opposed the constitutional era, especially the State Duma, laws of religious toleration and the bureaucracy, politics and parliament, which he placed in direct opposition to the purity of Russian science. ${ }^{54}$ The leaders of the student right across the empire continually expounded on the benefits of scientific study, and proclaimed the virtues of scientific development in their propaganda throughout the late imperial period. Leaders of the major rightwing groups reflected these student concerns. One of the leaders of the UAM, V. A. Obraztsov, claimed in a speech delivered in the State Duma on 2 March 1911 (later re-published in the right-wing newspaper Realm [Zemshchina]) that the university was a 'temple of science', and a left-leaning professoriate had lost sight of this crucial fact in recent years. ${ }^{55}$ This had led to lawlessness and anarchy on universities across the empire, and the main losers in this struggle were Russia's students themselves. ${ }^{56}$ In his own history of the student movement, penned in 1914, Vladimir Purishkevich claimed that one of the main aims of the Academists was to stop 'the spread of revolutionary literature in the temple of science ${ }^{57}$ Such criticisms of the modern Russian university were widely held amongst the Academists themselves.

Within Academist groups there was a clear link between science and nationalism, reflecting pan-European discourses about scientific culture. Academists 
were not reactionaries in every sense; some recent developments were received positively, including certain examples of technological progress. Scientific achievement was presented as a story of national progress: though figures from the history of European science such as Michael Farraday were cited as influences, science was seen primarily as an instrument with which to improve national culture. The chemist Dmitrii Mendeleev was cited as an example of a product of the Russian educational system before the time of revolution. He was specifically considered to be a national hero, rather than a figure whose intellectual achievements had been used for the good of humanity. ${ }^{58}$ This was not a celebration of science in and of itself: such developments showed the potential power of the Russian state as a modern, advanced nation. Like many civil society groups in late imperial Russia, Academist groups proclaimed the virtues of science and linked it to civic patriotism. ${ }^{59}$ The positive virtues of science were widely contrasted with the negative tendencies of politics and political development. ${ }^{60}$ In this sense, Academists looked forwards as well as backwards.

In addition to the positive virtues of science, Academists also praised sport and gymnastics, particularly as potential restorative measures to halt contemporary decline. The formation of sporting societies was linked to the wider organization of the student right after 1905. In Akkerman province, rightists established their own school, with a special focus on physical culture as an instrument for the reconstruction of Russian youth in the post-revolutionary era in order to repair the destructive effects of modern politics, creating an emphasis on healthy bodies as well as healthy minds. ${ }^{61}$ The Academist branch at the Forestry Institute in St. Petersburg had its own branch of the 'Russian Sport' circle. ${ }^{62}$ Gymnastic circles known as Berkut also appeared at Kazan University, led by their Academist group. ${ }^{63}$ The St. Petersburg Academic Union, which claimed to have 400 members in October 1907, claimed in its manifesto 
that its central principles were the support of science, art and sport, and the representation of all non-political interests at St. Petersburg University. These were closely linked to other right-wing associations: in a circular addressed to Purishkevich, the group requested 13,000 rubles from the main council of the UAM to build a library to house its various literary collections, and to hold musical, sporting and literary activities. ${ }^{64}$ Two other groups, the Russian Hero and Eagle, both appeared in Kiev during 1907. These groups were established to provide sporting opportunities to youth in the region, and were also linked to other right-wing movements in the region that had been active since late 1905, such as the Union of Russian Working Men and the Kiev branch of the Russian Assembly. Hundreds of students joined such organizations. ${ }^{65}$

This attachment to sport consisted of a desire to physically reconstruct Russian youth in an age of revolutionary decadence. Inspired by conservative student organizations such as the Dennitsa group that had existed in Russia before the revolution, but also the German student movement known as the Burschenschaften that had emerged in the mid nineteenth century and the German Gymnastic League (founded in 1848), Academist clubs claimed that sport was an innately beneficial activity. ${ }^{66}$ These groups promoted physical fitness, and 'truly Russian' values of brotherhood, companionship and order. Fears of the degenerate influences of political modernity were contrasted with a morally virtuous, physically able and patriotic youth. That one of the main inspirations for these gymnastic groups was a number of foreign groups such as the Burschenschaften shows that the student right's relationship with Europe and European ideologies was multifaceted. On the one hand, condemnation of internationalism by the major or 'national' right-wing groups that supported the Academists demonstrates a view that the ideology of this movement was anti-European in certain respects. ${ }^{67}$ Monarchists were widely suspicious of 
'European' ideologies such as socialism, atheism and nihilism, seeing their current crises as an inheritance of Europe's bad habits. ${ }^{68}$ Yet, conversely, Purishkevich, in common with others in the movement, thought that German nationalist youth movements had lessons that could be adapted to the Russian context; additionally, a number of other European countries had their own models that provided lessons for Russia's nationalist youth. In Britain, the universities of Oxford and Cambridge were looked upon with a great deal of approval due to their supposed emphasis on order, discipline and opportunities for physical education as well as their high intellectual quality. ${ }^{69}$ Therefore, foreign movements provided a number of examples that subsequently proved influential.

What linked these two obsessions - science and sport - together and indicates that Academists were part of a more radical presence was how these ideas were linked to the ultra-nationalism that embodied much of the Academist spirit. Both sport and science were not only held to be innately beneficial to students, but were connected to the broader project of raising the Russian spirit in the time of decadence. Indifferent to present realities, Academists looked both forwards and backwards in a search to construct a nationalist project that would restore Russia. Academist groups took their practical projects seriously and organized their own activities, entirely separate from official channels. They married long-existing ideas in Russian conservatism - such as the importance of Russian religion and support for the autocracy - with new plans and goals in the search for an alternative to Russia's current travails.

\section{The adoption of violence}

Some student groups on the right went further in registering their opposition to the status quo. Frustrated with the unrest at Russia's universities during 1905, some 
activists expressed increasing impatience in attempting to arrest what they saw as harmful changes. The most extreme form of this impatience was the adoption of violence. This was particularly evident in the troublesome Western borderland regions of the Russian Empire. In Odessa, student activists from the right began to mobilize during 1905-06 in response to revolutionary activities. This was clearly linked to the wider development of the right-wing movement and groups like the URP in Odessa; students were involved in some of the most aggressive right-wing groups, encouraged by sympathetic professors such as N. S. Mishenko. ${ }^{70}$ A report compiled on 25 November 1905 by senator N. A. Kuzminskii into the origins and spread of the pogroms that swept through Odessa during October specifically mentioned the presence of 'young people' amongst the crowds of pro-Tsarist demonstrators, who 'filed down the streets with icons, portraits of the Tsar and national flags'. ${ }^{71}$ The appearance of this unofficial, street variety of the organized right posed new challenges for the autocracy.

Student radicalism arose together with the wider formation of the radical right and particularly militant groups like the URP. In the months following the revolution, the activities of students can be clearly linked to the Odessa branch of this organization. At New Russia University gangs of URP activists caused significant consternation to students with threats of violence. A particularly crucial element of their relationship with the state was the response from the Ministry of the Interior: Russia's police. Reports claimed that they interrupted lectures, disrupted classes, and generally intimidated many members of the wider student body. The rector of New Russia University, I. M. Zanchevskii, even wrote to Petr Stolypin, Assistant Minister of the Interior, on the threat posed by bands of right-wing student activists as they targeted socialist and Jewish students. ${ }^{72}$ These student radicals from the right chanted "God, Tsar and Fatherland" and "Russia for the Russians!" threatening to attack any 
students that would stand in their way. ${ }^{73}$ Spurred on by the leadership of a prominent leader of the Odessa branch of the URP, Count Aleksei Konovnitsyn, these bands of student activists might number groups of no more than seven or eight, but were often armed and, as a result, were considered to be extremely dangerous by police, bringing the issue of student radicalism from the right to wider national attention. These bands of radical student groups appeared to copy many tactics from the demotic and nationalist Odessa URP. Both heavily anti-Semitic, they intimidated Jews and threatened Russia's Jewish population with violence. ${ }^{74}$

The Academists' use of violence cast doubt on their self-described role as defenders of the fatherland (otechestvo). Local police realized the close link between radical right-wing students and the URP, and took an active role in monitoring the student right from the end of 1906. Another report from Odessa in December 1906 claimed that 276 students linked to the URP were causing such disruption on the university that further action would need to be taken in order to apprehend the leaders of the movement. They were led and inspired by Baron Kaul'bars, one of the leaders of the Odessa branch of the URP. Though the majority of the student body had, it was claimed by police, 'anti-government' character, new measures would need to be considered to contain the threat of student radicalism from the right. Tsarist officials, shaken by the revolution, were concerned by the presence of these radicals from the right who mobilized precisely because, in their view, the autocracy was too weak to

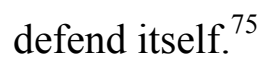

The responses of the authorities to right-wing students can clarify distinctions between autonomous right-wing radicals and the conservative Russian state. Some thought the energy of the movement could be tamed, or even used. In the wake of the revolution of 1905, the Minister of Education (1908-10), A. N. Shvarts, considered 
that rightist students might have had a useful impact on universities as a counterweight to left-wing radicalism. ${ }^{76}$ Moreover, it has been in several sources that the right-wing movement received generous funding from the state. The Assistant Minister of Internal Affairs S. E. Kryzhanovskii, who Konovnitsyn claimed diverted funding towards the Odessa right, ${ }^{77}$ recounted in his memoirs that right-wing activity was supported by the Ministry, a contention seconded by the then Minister of Finance (1904-14), V. N. Kokovtsov. ${ }^{78}$

Conversely, some within the Ministry of the Interior were deeply suspicious of the Academists. The threat that they posed to public order continued to be evident in the years immediately before the First World War. Academists were prominently involved in key anti-Semitic events such as the Beilis Affair of 1911-13. ${ }^{79}$ It was student radicals from the right who originally brought this episode to public prominence, in particular the rabble-rousing V. S. Golubev of St. Vladimir University who spread anti-Semitic propaganda across the surrounding area in an ultimately successful attempt to bring the matter to national attention. ${ }^{80}$ Golubev, a leading member of the Double-Headed Eagle, started the ritual murder allegation directed against Mendel Beilis, which ended up drawing international condemnation. ${ }^{81}$ The crude attempts of newspapers such as the Double-Head Eagle to exploit popular emotions by re-printing graphic images of the ritual murder mythos was of considerable concern to the local police, who monitored the activities of the DoubleHeaded Eagle closely, and took a dim view of the reactions evoked. ${ }^{82}$ Even when not partaking in actual violence, the ability of Academist groups to incite it attracted condemnation. The governor-general of Kiev, A. F. Girs, in a circular to police from February 1912 wrote: 'from the activity of the police we can clearly see that they are afraid of such 'unionists', with their ability to damage the peace in society and their appeal to the interests of narrow-minded philistines' ${ }^{83}$ Like in the case of student 
radicals in Odessa, the intransigent nature of these student movements caused concern amongst those responsible for keeping order in the vast and unstable empire. The Double-Headed Eagle was considered to be a vehement organization that would damage the fragile peace in the region; the authorities had not forgotten the impact of the revolution itself, when they had been too confused and disorganized to stop effectively events that had been feared by Russia's rulers for years.

\section{Support and endurance}

Though there was no eventual revolution from the right in the period, continuous support for Academist movements, as shown by the data at the beginning of this analysis, can prompt us to look at the movement afresh. This endurance prompts us to consider what lay behind the longevity of the student right, long after the revolutionary crisis of 1905 had been contained by the autocracy. First, Academists were never denied their primary enemy. Radicalism from the student left was always a reality in late imperial Russia, long after the revolution of 1905 had abated. In early 1911 at Moscow University, a number of students staged strikes and sit-ins. The student demonstrations against the autocracy that followed the funerals of S. A. Muromtsev and Leo Tolstoy were cited as evidence of student radicalism by the conservative press. One editorial claimed, 'it was perfectly clear from the Muromtsev and Tolstoy funerals long ago that these would open new pathways to revolution, and would start their recruitment from the young'. Though '99 per cent' of students were considered to be against strikes, the article betrayed fear that many students would be corrupted by these subversive trends. ${ }^{84}$ The Tolstoy funeral in 1910 was considered to be a particularly problematic event by rightist thinkers like Lev Tikhomirov, as the pacifist ideals of the late writer would further corrupt a student body laid low by revolutionary and socialist ideals. ${ }^{85} \mathrm{~A}$ letter from Academists at St. Vladimir 
University in Kiev also cited the funerals of Muromtsev and Tolstoy as particularly disruptive events that were creating new waves of left-wing radicalism, aspirations fed by the 'progressive' press such as Russian Word, Russian Messenger and others. ${ }^{86}$ Letters from student Academists, such as those at Moscow University, continually touched upon this and urged what they insisted was the student majority to rise against revolutionary agitators. ${ }^{87}$ For Academists, the idea that leftist student radicalism needed to be opposed was their primary motivation; revolutionary demonstrations were cited as evidence of the need for an affirmative rightist response. As Ernest Nolte wrote long ago, 'the origin of the right always lies in the challenge of the left', true also in late imperial Russia where the state's inability to control mobilization on both the right and the left created additional space for a public battle between various factions. ${ }^{88}$

A second reason for Academist endurance was the financial support given to the movement, which gave Academists the ability to enact their ideas. But it is not always easy to pinpoint the sources of their funding. Support from above was certainly crucial to Academist groups: they received money from the major, national right-wing groups. Clearly the UAM had a particularly close relationship with its Academist groups. Major figures such as V. M. Purishkevich, A. A. Bobrinskii and V. A. Obraztsov supported the movement by attending their meetings and clubs. In one case, a delegation led by Purishkevich met with leaders of the Kiev Academist Union on 8 March 1911. G. G. Zamyslovskii and Purishkevich gave thanks to those who had gathered to listen, claiming that the Academists represented the "best parts of Russian society'. ${ }^{89}$ Senior rightists continued to support the Academists, even as their most vehement members like Golubev were attracting condemnation from elsewhere, including from within the autocracy. 
Groups including the UAM also financially supported the Academists. Letters from Academists to Purishkevich at the main council of the UAM in St. Petersburg specifically asked for his help, often in obsequious fashion. ${ }^{90}$ Kushnyr'-Kushnarev was also keen to provide financial assistance to the students in the Znanie group at the Forestry Institute, with students from the association writing letters to him thanking for him for his financial support, though the exact specifics and extent of this support is not always recorded. ${ }^{91}$ The contributions of another leading figure are easier to pin down. One letter penned in 1908 from L. Kazanov, a member of the St. Petersburg Academic Union, thanked Purishkevich for his generous financial support, recording receipt of 500 rubles. Other letters from students at the same institution also wrote to Purishkevich thanking him for supporting their ventures. ${ }^{92}$ Many police sources contain letters circulated between members and organizers of the Znanie group at the Forestry Institute, which claim that they received financial support from V. M. Purishkevich during 1913. It is not always easy to find specific details in these letters and notes, but they usually imply that their main sources of funding originated from within the rightist movement, including from the leader of the UAM himself. ${ }^{93}$

A third reason for the longevity of the movements was the piecemeal toleration that Academist groups were shown by major ministries in Russia. This appeared to be the case particularly once the most extreme violence associated with the revolutionary years had subsided. Some documents claim that the Ministry of Finance was active in funding such groups, and that it increasingly relied on its support in the final years of tsarism. In contrast, others claim that assistance largely came from within the right-wing movement. Academist leaders such as V. M. Purishkevich enjoyed a close relationship with certain figures in the tsarist establishment. The UAM leader wrote a series of letters to the Minister of Education from 1910, Lev A. Kasso, who apparently received the movements fairly 
sympathetically. ${ }^{94}$ The leader of the Constitutional Democrat (Kadet) Party, Pavel Miliukov, claimed that the government funded Purishkevich's ventures. He claimed this trend that increased in scale during elections to the Third and Fourth State Dumas. ${ }^{95}$ Isolated and fragmentary evidence does support some of these claims, if not perhaps to the same extent that Miliukov claimed in his memoirs. For instance, a telegram from 1 December 1913, from an unknown sender, addressed to the deputy director of the department of police in St. Petersburg, S. P. Beletskii, thanked the director for his financial assistance and support of the Znanie group at the Forestry Institute. The figures claimed range between 50 and 100 rubles, with a number of telegrams claiming support from within the police. Other telegrams circulated within the same police department from the November of that year note the financial support given by the police to the Academist groups. ${ }^{96}$

The notion that the state actively sought to fund the Academists has been challenged by the rightist groups themselves, which claimed not to be in receipt of any state funding. However, other sources from the right claim the reverse: one report from within the Odessa branch of the URP in 1909 stated that the organization in the city received financial support from the police, which was mainly put towards building a school. ${ }^{97}$ The picture that emerges from these sources is complex. Unlike documents on the ideology of the movement, which give a crystal clear view of their central beliefs, sources of funding are difficult to pin down with real precision. In any event Academists did clearly receive some funding from sources within the state, though in most cases their main financial supporters appeared to be within the major rightist parties and groups. Of course, a further question is where these parent groups got their own funding from; it is possible that Academists were absorbing funding from the Ministry of Finance second hand, as they were in receipt of support from the national groups that themselves had received government subsidies. ${ }^{98}$ 
Aside from financial disbursements, rightist students their leaders could gain the support of significant figures from within the imperial state. When the rector of St. Petersburg University banned Kyshnyr'-Kushnarev in early 1914 from giving lectures at the university, presumably on the grounds of seeing him as a troublesome agitator, the Minister of Education, Lev A. Kasso, intervened with a written request for the rector to provide a better explanation for his expulsion. Kasso claimed that he was not satisfied with the rector's actions and that he would need to clarify his position, or else he would force him to allow Kushnyr'-Kushnarev re-admittance to the grounds of the university. This report cited the actions of Kushnyr'-Kushnarev in establishing the Znanie organization, which Kasso claimed had brought a degree of stability to the university in the period after the revolution. ${ }^{99}$ This raises the question as to why Russia's rulers would countenance the support of what were sometimes seen as radical groups. To arrive at an answer is not easy: the tsarist state did not have a monolithic structure, and contained within it a variety of different, even competing, interest groups. The student disorders on universities during 1905 appeared to bring a degree of toleration for the Academist movement on the part of the establishment, chiefly in its potential use as a counterweight to revolutionary student groups. However, the institutions and structures of the Russian state were conflicted in their response towards developments from an autonomous right, especially in light of violent practices and rightists' intransigent stance towards political and social developments. The picture that emerges from these sources is complex; there was a measure of half-hearted support for a nascent student right that included a degree of funding for their groups, but rarely the distribution of weapons, and, perhaps most telling of all, no shared ideological platform.

\section{Conclusion}


Inspired by the revolution of 1905 and continued fears of left-wing unrest, Academist groups spread across the empire, and lasted until the revolutions of 1917. They were particularly concentrated in the Western borderlands, with branches active in Khar'kov, Kiev, Warsaw and Odessa, but were also present in Moscow and St. Petersburg. Throughout the period, major right-wing groups such as the UAM supported the Academists. It is clear that the Academists also worked to develop their own projects as part of a wider struggle from the right against change in Russia, and, in particular, a strong opposition to revolutionary politics. Activists sought to oppose harmful political doctrines by praising Russian religion, the pursuit of science and physical reconstruction through sport. This article has contended that the Academists were part of a more radical presence emerging on the right after 1905, but they were not insurrectionists and contained elements of conservative doctrines long established. Most notable of these was their support for the principles of Russian religion and Russian autocracy. It is most accurate, therefore, to speak of a multifaceted right, and an unstable mixture of conservative doctrine with a new style and energy that illustrates the diversity of the right as it emerged in the early twentieth century.

Academists were deeply pessimistic: they opposed contemporary developments and were clearly unhappy at what they saw as the many discontents of Russian progress. Critics of the status quo, they saw little worthy of conserving in the current epoch and developed an independent vision for the restoration of Russia in the future. Like their parent organizations such as the URP and UAM, piecemeal funding of Academist movements did not reign in criticisms of the status quo or dampen their intransigent temperament. Funding the right in order to make it more compliant, in the long term, proved to be a foolhardy strategy that did not in fact shore up conservative opinion in favour of the autocracy. ${ }^{100}$ The instability in Russian 
conservatism is well reflected by the state's uneasy responses to Russia's radical right students, oscillating between a degree of toleration and fear of these new groups that had accurately surmised the weakness of the tsarist autocracy.

Activists drew on new elements as part of a wider struggle against modernity in Russia. They were often vehemently chauvinistic and anti-Semitic in their doctrine, which highlights a more intransigent presence amongst such groups. Their rejection of the October Manifesto - the so-called 'Witte constitution' - showed that Academists were out of step with some of the major political developments of the age. Activists like Golubev went even further, decrying the new settlement as the work of 'liberal Jewish' progressives. ${ }^{101}$ The deepest challenge that right-wing students posed in Russia was in their occasional adoption of violence: that this occurred in the borderland areas such as Odessa and Kiev was especially problematic for the autocracy. This deep unease and radical opposition to the tsarist status quo led perceptive observers like Sergei Kryzhanovskii to later speculate upon the similarity between the far right and the far left in the late imperial period. Both factions were aggressive populists; both were positioned against the status quo. ${ }^{102}$ Russian rightists claimed to be defending the Russian autocratic state, but they were certainly not defending it in its present form - nor were they particularly enamoured with the personality of Nicholas II. ${ }^{103}$

In common with a number of tendencies elsewhere in Europe, Academist clubs sought to use nationalist ideas in the age of popular politics, as seen by their creation of various clubs and societies after the revolution. They developed an ideology separate from the state, following Uvarov's major principles but also shown interests in science and sport as part of a planned revival of Russia. Obsessive in pursuit of these plans, and harshly decrying the realities of the Russian present, 
Academists had a foot in both the past and the future - they were intemperate nationalists who nevertheless refused to let go of doctrinal certainties inherited from centuries of tsarism. This led to a dilemma amongst the groups, one prompted by the conditions of modernity in late imperial Russia. The appearance of a student right, even if ostensibly in support of the principle of autocracy, in itself implied that the educational projects of the tsarist state had not been entirely successful in years hence; rather than only co-opt tsarist loyalists, Academists sought to attract followers from the increasingly restive student body. Though not successful to the extent that leaders had hoped for, Academists nevertheless formed one important component of the 'discordant choir' that exemplified the resistance to liberalism that emerged in the public sphere of life in late imperial Russia. ${ }^{104}$

\footnotetext{
${ }^{1}$ Gosudarstvennyi arkhiv Rossiiskoi Federatsii (hereafter, GARF), F. 102, 4-e d-vo, op. 1907, d. 128, 1. 1: Kievskii golos, 2 February 1907.

${ }^{2}$ On the major right-wing groups see for example the work of H. Rogger, Jewish Policies and RightWing Politics in Imperial Russia (Berkeley and Los Angeles 1986); D. C. Rawson, Russian Rightists and the Revolution of 1905 (Cambridge 1995); Iu. I. Kir'ianov, Pravye partii v Rossii. 1911-1917 (Moscow 2001); I. V. Omel'ianchuk, Chernosotennoe dvizhenie v Rossiiskoi imperii, 1901-1914 (Kiev 2007); Z. Vydra, Život za Cara? Krajní pravice v předrevolučním Rusku (Prague 2010).

${ }^{3}$ Iu. I. Kir'ianov and B. F. Dodonov (eds.), 'Predystoriia pravomonarkhicheskikh partii v Rossii, $1902-$ 1905 gg.', Istoricheskii arkhiv, No. 5 (2001), 115.

${ }^{4}$ Iu. I. Kir'ianov, ed., 'Pravye i konstitutsionnye monarkhisty v Rossii v 1907-1908 gg.', Voprosy istorii, No. 8 (1997), 94-95.

${ }^{5}$ GARF, F. 102, 4-e d-vo, op. 1907, d. 164, 1. 297 ob.: police report, Ekaterinoslav district, 24 October 1908.

${ }^{6}$ Iu. I. Kir'ianov, ed., 'Pravye i konstitutsionnye monarkhisty v Rossii v 1907-1908 gg.', Voprosy istorii, No. 6 (1997), 112.

${ }^{7}$ GARF, F. 102, 4-e d-vo, op. 1907, d. 164, 11. 27-27 ob.: undated police report from Warsaw (circa late 1908).

${ }^{8}$ Figures cited in S. A. Stepanov, Chernaia sotnia v Rossii, 1905-1914 gg. (Moscow 1992), 105. These are based on police records collated in what is now GARF F. 102.00 (the Department of Police Special Section).

${ }^{9}$ Priamoi put', 31 January 1911, 673, 'U akademistov. Otrkrytie akademicheskogo kluba v Odesse'.
} 
${ }^{10}$ GARF, F. 102.OO, op. 316, (1913 g.), d. 313, 'O vydache posobii studentam akademicheskoi korporatsii s S. Peterburgskogo universiteta i Lesnogo instituta': 27 September 1913-17 April 1914.

${ }^{11}$ Vneshnaia vody. Sbornik nauchno-literaturnogo kruzhka russkikh studentov. Pod redaktsiei Mikh. Spasovskogo (St. Petersburg 1914), 12-13.

${ }^{12}$ Nationalist activity in the right-bank Ukraine and analysis of the Ukrainian question in a broader perspective can be found in a recent monograph, F. Hillis, Children of Rus': Right-Bank Ukraine and the Invention of a Russian Nation (Ithaca, NY 2013).

${ }^{13}$ See for example A. V. Repnikov, Konservativnye modeli Rossiiskoi gosudarstvennosti (Moscow 2014); and M. Luk'ianov, Rossiiskii konservatizm i reforma, 1907-1914 (2nd ed., Stuttgart 2006).

${ }^{14}$ Uvarov's triad was first promulgated in 1831 as a response to the rise of ideologies that challenged the social and state structure of imperial Russia, and was the first notable attempt by the autocracy to define its own ideology. For further analysis see P. Waldron, 'The Legacy of Count Sergei Uvarov', in M. Branch, ed., Defining Self: Essays on Emergent Identities in Russia, $17^{\text {th }}$ to $19^{\text {th }}$ centuries (Helsinki 2009), 211-223; and C. H. Whittaker, The Origins of Modern Russian Education: An Intellectual Biography of Count Sergei Uvarov, 1786-1855 (DeKalb, IL 1984); on the adoption Uvarov's principles by Russia's nineteenth-century conservatives, see V. Ia. Grosul, ed., Russkii konservatizm XIX stoletiia: ideologiia i praktika (Moscow 2000).

${ }^{15}$ M. Loukianov and M. D. Suslov, 'Defenders of the Motherland or Defenders of the Autocracy?' Kritika, Vol. 13, No. 1 (2012), 223.

${ }^{16}$ Kir'ianov, Pravye partii v Rossii, 57.

${ }^{17}$ On these two groups, see, respectively, D. B. Pavlov, 'The Union of October 17', in A. Geifman, ed., Russia Under the Last Tsar: Opposition and Subversion, 1894-1917 (Oxford 1999), 179-198; D. A. Kotsiubinskii, Russkii natsionalizm v nachale XX stoletiia. Rozhdenie i gibel' ideologii vserossiiskogo natsionalnogo soiuza (Moscow 2001).

${ }^{18}$ See, typically, M. V. Borisenko, 'Vliianie opyta pervoi rossiiskoi revoliutsii na formirovanie obshchestvennogo oblika rossiiskogo studenchestva v mezhrevoliutsionnyi period (1907-1917 gg.)', in Iu. D. Margolis, ed., Novoe o revoliutsii 1905-1907 gg. v Rossii: mezhvuzovskii sbornik (Leningrad 1989), 165-176; P. S. Gustiatinkov, Revoliutsionnoe studencheskoe dvizhenie v Rossii. 1899-1907 (Moscow 1971); N. Ia. Olesich, V. I. Lenin i revoliutsionnoe studenchestvo Rossii (Moscow 1982).

${ }^{19}$ For instance, Don Rawson's study of the right from 1905-07 makes only very fleeting reference to right-wing students. Recent Russian studies are I. V. Omel'ianchuk, 'Monarkhicheskie 'akademicheskie korporatsii' v uchebnykh zavedeniiakh Rossii (1901-1914 gg.)', <http://ukrstor.com/ukrstor/omeljancuk-akademobszestva.html $>\quad$ (accessed 12/10/2014); Chernosotennoe dvizhenie, 128-142; S. A. Stepanov, Chernaia sotnia v Rossii ( $3^{\text {rd }}$ ed., Moscow 2013), 441-458.

${ }^{20}$ S. Morrissey, Heralds of Revolution: Russian Students and the Mythologies of Radicalism (Oxford 1998), 67, 78-80, 140-146; 'From radicalism to patriotism? Petersburg students between two revolutions, 1905 and 1917', Revolutionary Russia, Vol. 13, No. 2 (2000), 20-44.

${ }^{21}$ On the Russian Assembly, see Iu. I. Kir'ianov, Russkoe sobranie (Moscow 2003). Also useful are H. Rogger, 'The Formation of the Russian Right, 1900-1906', California Slavic Studies, Vol. 3 (1964), 66-94; Rawson, Russian Rightists, 46-55; and Vydra, Život ot Cara? 59-71.

${ }^{22}$ See 'O nastroenii russkoi molodezhi' in A. S. Viazigin, V tumane smytnykh dnei (Khar'kov, 1908), 191, originally published in Mirnyi trud, 1904, No. 7; see also Mirnyi trud, 1904, No. 9, 229, 'Po povodu studencheskikh bezporiadkov'.

${ }^{23}$ A review of the organization's work from 1902-04 includes an assessment of how to appeal to students. Mirnyi trud, 1904, No. 1, Part 2, 51; see also GARF, F. 588, op. 1, d. 1368, which contains 
records from the student organizations during 1904, including letters sent to the Assembly from their student followers.

${ }^{24}$ Kir'ianov and Dodonov (eds.), 'Predystoriia pravomonarkhicheskikh partii v Rossii', 118.

${ }^{25}$ Ibid., 119.

${ }^{26}$ Mirnyi trud, 1904, No. 1, Part 2, 51.

${ }^{27}$ Mirnyi trud, 1904, No. 7, 151-158, 'O nastroenii russkoi molodezhi'; 1904, No. 9, 226-233, 'Po povodu studencheskikh bezporiadkov'; see also Viazigin, V tumane smytnykh dnei, 189-197.

${ }^{28}$ The three cities I have cited here contained the universities with the greatest percentage of Jewish students in the late imperial period. As a proportion of the total student body, figures from the imperial census of 1897 give 11.6 per cent for Warsaw, 11.8 per cent for New Russia (Odessa) and 15.2 per cent for St. Vladimir (Kiev) Universities respectively. Further data is in G. Hausmann, 'Der Numerus clausus für jüdische Studenten im Zarenreich', Jahrbücher für Geschichte Osteuropas, Vol. 41, No. 4 (1993), 513. Two recent assessments of left-wing radicalism are M. F. Hamm, 'On the perimeter of revolution: Kharkiv's academic community, 1905', Revolutionary Russia, Vol. 15, No. 1 (2002), 4568; M. C. Hickey, 'People with pure souls: Jewish youth radicalism in Smolensk, 1900-1914', Revolutionary Russia, Vol. 20, No. 1 (2007), 51-73.

${ }^{29}$ The rightist youth group the Double-Headed Eagle was present at several of his speeches that were delivered at public meetings. These would also attract rightist workers' groups and peasants from the region that sympathized with their cause. See B. M. Iuzefovich, Politicheskie pis'ma: materialy dlia russkogo politicheskogo umopomracheniia na rubezh' dvukh' stoletii (1898-1908 gg.), Vol. 9 (Kiev 1908), 330-332.

${ }^{30}$ On Krushevan's role see E. H. Judge, Easter in Kishinev: Anatomy of a Pogrom (New York 1992); see also the testimony of the governor of Bessarabia, Prince S. D. Urusov, Memoirs of a Russian Governor (London and New York, reprinted 2012), 79-80.

${ }^{31}$ The best overall history of 1905 remains A. Ascher, The Revolution of 1905, 2 vols. (Stanford 1988 and 1992).

${ }^{32}$ Grazhdanin, 1905, No. 26, 6-7, 'Pis'mo studenta'.

${ }^{33}$ On the right's criticisms of the 17 October Manifesto see Rawson, Russian Rightists, 27, 29, 39-40, $53,66,68,69,81,105,114$.

${ }^{34}$ Some useful overviews of the URP can be found in Rawson, Russian Rightists, 56-72; H. Rogger, 'Was There a Russian Fascism? The Union of Russian People', Journal of Modern History, Vol. 36, No. 4 (1964), 398-415; Vydra, Život ot Cara? 108-119.

${ }^{35}$ The government's decision to shut the universities and the political wrangling over their subsequent reopening is recounted in S. D. Kassow, Students, Professors and the State in Tsarist Russia (Berkeley 1989), 275-279.

${ }^{36}$ GARF, F. 117, op. 1, d. 120, 11. 1-2 ob.: ob"iasnitel'naia zapiski. This is a circular from the main council of the Academist group (Znanie) at the Forestry Institute in St. Petersburg. A very short biography of Kushnyr'-Kushnarev is in A. D. Stepanov and A. A. Ivanov, eds., Chernaia sotnia: Istoricheskaia entsiklopediia (Moscow 2008), 280.

${ }^{37}$ V. M. Chernovskii and V. P. Viktorov, eds., Soiuz russkogo naroda (Moscow and Leningrad 1929), 289

${ }^{38}$ See for example a report, Mirnyi trud, 1909, No. 5, 48, 'deiatel'nost' Russkago zhenskago kruzhka uchshchikhsia g. Moskvy'.

${ }^{39}$ GARF, F. 102, 4-e d-vo, op. 1907, d. 128, 11. 7-8: rules and regulations of the Double-Headed Eagle.

${ }^{40}$ Ibid., 11. 8-9.

${ }^{41}$ Ibid., 1. 8. 
${ }^{42}$ V. M. Purishkevich, Pred grozoiu: pravitel'stvo i russkaia narodnaia shkola (St. Petersburg 1914), 6-7.

${ }^{43}$ GARF, F. 117, op. 2, d. 8, 11. 83-83 ob.: flyer from the organizational bureau of the Academist Union at the St. Petersburg Polytechnic Institute; see also GARF, F. 117, op. 1, d. 119, 1. 23: 'obrazhenie k nezavisimoi i bezpartiinoi chasti studenchestva', which contains a circular from Znanie at the Forestry Institute, based in a suburb of St. Petersburg. This circular starts with an identical message.

${ }^{44}$ Mirnyi trud, 1905, No. 11, 212.

${ }^{45}$ Priamoi put', March 1914, 284, 'Russkaia shkola'.

${ }^{46}$ GARF, F. 117, op. 2, d. 8, 11. 46-48.

${ }^{47}$ Priamoi put', 23 October 1910, 405, 'Pis'ma po universitetskim delam'.

${ }^{48}$ Priamoi put', 30 May 1911, 43, 'Ispoved' studenta'.

${ }^{49}$ Moskovskie vedomosti, 1905, No. 274, 2, 'Russkaia monarkhicheskaia Partiia'.

${ }^{50}$ GARF, F. 117, op. 2, d. 8, 1. 13: this collection includes a list of members of the main council of the Academists at the St. Petersburg Polytechnic Institute, collating 32 names.

51 '[Informatsionnoe pis'mo] ot glavnoi palaty Russkogo narodnogo soiuza imeni Mikhaila Arkhangela', in Kir'ianov, ed., Pravye partii, Vol. 1, 402-404.

${ }_{52}$ Mirnyi trud, 1907, No. 5, 107, 'vtoroe godovoe zasedanie "kruzhka russkikh studentov"'.

${ }^{53}$ Priamoi put', 23 October 1910, 255, 'Pis'ma studentov k V. M. Purishkevichu'.

${ }^{54}$ On this point see for example GARF, F. 117, op. 2, d. 8, 1. 1: k studenchestvu s Peterburgskogo politekhnikuma (1908). This is a flyer from the Academic Union at the St. Petersburg Polytechnic addressed to all other students at the university.

${ }^{55}$ V. A. Obraztsov, Universitet-khram nauki. Rech' chlena gosudarstvennoi dumy V. A. Obraztsova, proizmesennaia 2 Marta v gosudarstvennoi dume. "Po zaprosu o vysshei shkole" (Ekaterinburg 1911), 14-15; originally published in Zemshchina, 4 March 1911.

${ }^{56}$ Ibid., 15.

${ }^{57}$ Purishkevich, Materialy po voprosu, 77.

${ }^{58}$ Chernovskii and Viktorov, eds., Soiuz russkogo naroda, 244; see also a report in Mirnyi trud, 1907, No. 5, 107, "vtoroe godovoe zasedanie "kruzhka russkikh studentov"'.

${ }^{59}$ On science and civil groups see J. Bradley, 'Subjects into Citizens: Societies, Civil Society, and Autocracy in Tsarist Russia', American Historical Review (2002) 1094-1123.

${ }^{60}$ Chernovskii and Viktorov, eds., Soiuz russkogo naroda, 244.

${ }^{61}$ Priamoi put', December-January 1911/1912, 360, 367-368, 'Sokol'skaia gimnastika i sport'.

${ }^{62}$ Priamoi put', February 1912, 103.

${ }^{63}$ Ibid., 111.

${ }^{64}$ GARF, F. 117 , op. 1, d. 119, 1. 5 ob.: police report describing the activities of the St. Petersburg Academic Union in, 7 October 1909.

${ }^{65}$ Omel'ianchuk, Chernosotennoe dvizhenie, 171-172.

${ }^{66}$ On gymnastic societies in Germany see G. L. Mosse, The Nationalization of the Masses: Political Symbolism and Mass Movements in Germany from the Napoleonic Wars Through the Third Reich (New York 1975), 127-136.

${ }^{67}$ See, for example, Rawson, Russian Rightists, 25-26, which notes the rejection of a Western-style parliament by Vladimir Gringmut.

${ }^{68}$ Moskovskie vedomosti, 1908, No. 202, 1, 'Professura i politika'.

${ }^{69}$ Priamoi put', 31 January 1911, 702, 'Angliiskii student.' Communications between the UAM central council and Academist Unions in St. Petersburg claimed to want to provide an education 'on a level with the best or with European schools, giving to Russian youth a good scientific education and a healthy religious, moral and national education'. GARF, F. 117, op. 1, d. 183, 1. 3. 
${ }^{70}$ Chernovskii and Viktorov, eds., Soiuz russkogo naroda, 242-244.

${ }^{71}$ Materialy $k$ istorii russkoi kontr-revoliutsii. Vol. 1: pogromy po offitsial'nym dokumentam (St. Petersburg 1908), 101.

${ }^{72}$ GARF, F. 102.OO, op. 316, (1905 g.), d. 999 ch. 39, 1. A, t. 1, 11. 15-15 ob.: telegram, I. M. Zanchevskii to P. A. Stolypin, 11 September 1906.

${ }^{73}$ Ibid., $1.15 \mathrm{ob}$.

${ }^{74}$ Ibid., 1. 10: Russkie vedomosti, 12 September 1906; see also a sympathetic report on the Odessa section in Mirnyi trud, 1907, No. 5, 113-114, "Vtoroe godovoe zasedanie "kruzhka russkikh studentov"'.

${ }^{75}$ The full police report, sent to P. A. Stolypin, is in GARF, F. 102.OO, op. 316, (1905 g.), d. 999 ch. 39 , 1. A, t. 1, 11. 89-93 ob.

${ }^{76}$ V. M. Purishkevich, Materialy po voprosu o razlozhenii sovremennogo russkogo universiteta (St. Petersburg 1914), V-VII.

${ }^{77}$ Chernovskii and Viktorov, eds., Soiuz russkogo naroda, 277.

${ }^{78}$ S. E. Kryzhanovskii, Vospominaniia (Berlin 1938), 156-158; V. N. Kokovstov, Iz moego proshlogo. Vospominaniia. 1903-1919 gg. (Moscow 1992), 9-12. The disbursements claimed by Kokovtsov are very large: 200,000 rubles a year during Stolypin's premiership to Nikolai Markov's newspapers Kurskaia byl' (Kursk's Past) and Zemshchina (Realm).

${ }^{79}$ There is a large body of secondary literature on the Beilis Affair. See, for instance, the recent work by R. Weinberg, Blood Libel in Late Imperial Russia: The Ritual Murder Trial of Mendel Beilis (Indiana 2013).

${ }^{80}$ A biographical sketch of this figure is T. Kal'chenko and A. Stepanov, 'Student-chernosotenets: Vladimir Stepanovich Golubev (1891-1914)', in A. A. Ivanov and S. D. Stepanov (eds.), Voinstvo Sviatogo Georgiia: zhizneopisaniia russkikh monarkhistov nachala XX veka (St. Petersburg 2006), 643-649.

${ }^{81}$ Ibid., 684-685.

${ }^{82}$ Iu. I. Kir'ianov, ed., 'Perepiska i drugie dokumenty pravykh 1911-1913 gody', Voprosy istorii, No. 10 (1999), 118.

${ }^{83}$ Chernovskii and Viktorov, eds., Soiuz russkogo naroda, 380. It should be noted that right-wingers were often described as unionists [soiuzniki] in such reports.

${ }^{84}$ Moskovskie vedomosti, 1911, No. 29, 1, 'Moskva 5 fevralia, universitetskii krizis'.

${ }^{85}$ L. Tikhomirov, 'Iz dnevnika L. Tikhomirova', Krasnyi arkhiv, 1(74) (1936), 181. For analysis of the funeral, see W. C. Nickell, The Death of Tolstoy: Russia on the Eve, Astapovo Station, 1910 (London 2010), 132-135; P. Kolsto, 'Mass for a Heretic? The Controversy over Lev Tolstoi's Burial', Slavic Review, Vol. 60, No. 1 (2001), 75-95; R. Bartlett, Tolstoy: A Russian Life (London 2011), 414-415.

${ }^{86}$ Priamoi put', 23 October 1910, 406, 'Pis'ma po universitetskim delam'.

${ }^{87}$ Priamoi put', February/March 1911, 890, 'Studenty-akademisty Mosk. universiteta'.

${ }^{88}$ Cited in E. Weber, 'Introduction', in H. Rogger and E. Weber, eds., The European Right: A Historical Profile (Berkeley 1966), 17.

${ }^{89}$ Priamoi put', 30 April 1911, 1088, 'Torzhestvo vo 2-m akademicheskim klube'.

${ }^{90}$ GARF, F. 117, op. 1, d. 119, 1. 42: letter from rightist students to the Union of the Archangel Mikhail, 13 January 1910 (unsigned).

${ }^{91}$ GARF, F. 117, op. 1, d. 120, 1. 3: circular from the main council of the Academist Union at the Forestry Institute, St. Petersburg, 20 August 1911.

${ }^{92}$ GARF, F. 117, op. 2, d. 8, 11. 36, 37, 40, 51: letters from Academists to V. M. Purishkevich. 
${ }^{93}$ GARF, F. 102.OO, op. 316, (1913 g.), d. 313, 11. 5-9: hand written letters from five members of Znanie at the Forestry Institute (surnames: Rusukom, Boichenko, Litinskom, Poliakov and Prachgom), addressed to V. M. Purishkevich.

${ }^{94}$ These were sometimes re-published in journals such as Priamoi put', for example 23 October 1910, 245, 'Po universitetam'.

95 A. P. Mendel, ed., C. Goldberg, trans. P. Miliukov, Political Memoirs 1905-1917 (Ann Arbor 1967), 279-280.

${ }^{96}$ GARF, F. 102.OO, op. 316, (1913 g.), d. 313, 1. 29: telegram addressed to S. P. Beletskii, 1 December 1913; 11. 34-34 ob.: note on the receipt of a sum by a student at St. Petersburg University, S. A. Litinskii, 6 November 1913.

${ }^{97}$ Chernovskii and Viktorov, eds., Soiuz russkogo naroda, 289.

${ }^{98}$ S. E. Kryzhanovskii claimed that the URP was in receipt of 15,000 rubles a month from Stolypin, much of which was used to fund newspapers such as Russkoe znamia (Russian Flag). Kryzhanovskii, Vospominaniia, 156-158.

${ }^{99}$ Priamoi put', March 1914, 279, 'Po universitetam'.

${ }^{100}$ For wider contextualization of this point, see P. Waldron, Between Two Revolutions: Stolypin and the Politics of Renewal in Russia (London 1998), 83-84.

${ }^{101}$ Cited in Kalchenko and Stepanov, 'Student-chernosotenets Vladimir Stepanovich Golubev', 686.

102 Kryzhanovskii, Vospominaniia, 152-153.

${ }^{103}$ See S. Podbolotov, 'Monarchists Against Their Monarch: The Rightists' Criticism of Tsar Nicholas II', Russian History, Nos. 1-2 (2004), 105-120.

${ }^{104}$ On this point more widely see L. Engelstein, Slavophile Empire: Imperial Russia's Illiberal Path (Ithaca and London 2009), 1-12. 